\title{
Kunibert Raffer*
}

\section{Rethinking Sovereign Debt: Pleading for Human Rights, the Rule of Law, and Economic Sense}

DOI 10.1515/ael-2015-0015

Published online June 17, 2016

\begin{abstract}
Reviewing and commenting on Lienau's book Rethinking Sovereign Debt, Politics, Reputation, and Legitimacy, this paper agrees with most of her points, aiming at supporting and complementing rather than contradicting her line of argument. It wants to corroborate her points as well as to bring up aspects that the book does not discuss. It presents two main comments on the more civilized treatment of sovereign debtors before WWII, and on the role of the Bretton Woods Institutions after 1945 that - as Lienau correctly notes changed the positon of debtors fundamentally. The paper shows that going further back into history than the book did, namely sovereign debts in the nineteenth century, strongly corroborates Lienau's line of argument regarding the period before WWII. The paper complements the role of the Bretton Woods Institutions with further facts, arguing that their strongly statist view is also self-serving and helpful to support multilateral lending practices violating these institutions' statutes. Finally, the new tendency back to a non-statist regime she rightly observes is commented on, pointing out that present debt management in the eurozone constitutes a considerable backlash.
\end{abstract}

Keywords: insolvency, sovereign debt restructuring, international finance

\author{
Table of contents \\ 1 Paradise lost: when lending was still more in line with the rule of law and market efficiency \\ 2 Institutional self-interest in violating one's own statutes \\ 2.1 Subordination rather than preference \\ 2.2 Lack of liability and misallocation of resources \\ 3 Recent tendencies back to non-statism? \\ 4 Conclusion \\ References
}

*Corresponding author: Kunibert Raffer, Department of Economics, University of Vienna, Oskar-Morgenstern-Platz 1, Vienna A1090, Austria, E-mail: unibert.raffer@univie.ac.at; kunibert.raffer@gmx.at 


\section{List of Symposium Papers}

1 “A Symposium on Sovereign Debt and Reputation” by Odette Lienau

2 "Sovereign Debt Restructuring, Refinancing and the Financial Market: A Comment on Lienau's 'Rethinking Sovereign Debt'” by Yuri Biondi

3 "The Rise of the Notion of Illegitimate Debt: a Comment on 'Rethinking Sovereign Debt: Politics, Reputation, and Legitimacy in Modern Finance' by Odette Lienau” by Tomoko Ishikawa

4 “A Role for Legitimacy in Sovereign Debt: A Review Essay on Odette Lienau, 'Rethinking Sovereign Debt" by Barry Herman

5 "Rethinking Sovereign Debt: Pleading for Human Rights, the Rule of Law, and Economic Sense" by Kunibert Raffer

6 "Embedded Contracts and a Continuum of Sovereign Debt" by Odette Lienau

Debt crises within Euroland, debatable decisions of a US federal judge in re Argentina $v$ NML Capital Ltd that fundamentally changed routine practices in sovereign capital markets, and efforts of the United Nations' (UN's) General Assembly to establish a new legal framework for debt restructuring have stimulated both discussions and political activities. Not that long ago UNCTAD (UN Conference on Trade and Development) published its Draft Principles on Promoting Responsible Sovereign Lending and Borrowing (on these principles $v$. Espósito, Li \& Bohoslavsky, 2013). Sovereign debt has once again become a hot topic. Consequently, publications abound.

Lienau's book stands out of the bulk, putting sovereign debt into a long term theoretical perspective and discussing important issues. She focuses on the distinction between a statist repayment rule - or sovereign continuity - and the non-statist perception of sovereignty, suggesting that debt should not be continuous in exceptional cases. Conflictive as they may usually be seen, these two views are not totally antithetic. The non-statist view also recognises that debts incurred by a prior government usually have to be honoured, only positing that this is not always so. In closely circumscribed cases the new government need or must not honour debts incurred by its predecessor. The reasons for discontinuity are few and more or less clearly defined. Lienau (2014, p.4) rightly assumes that alternative approaches to present practice "could function more fully in the future." Her conclusion that efforts for change "run up against powerful practices of debt continuity" Lienau (2014, p.4) could be formulated less diplomatically: as long as you can squeeze out payments from your debtor, theory is not important. Rather than legal theories, it is the pound of flesh that matters. Looking at Greece and her official creditors, especially her main creditor, Germany, itself still a contractual debtor to Greece (if one sank deep enough to call money extorted by Nazi Germany a contract), Shakespeare's one "pound of flesh" looks already exceedingly philanthropic. Much abused Shylock shows 
more mercy than Germany or the EU. Greed and contempt for human rights explain why the norm of debt continuity gained that much power. Unlike domestically, no human rights and Rule of Law based international law prohibits present practice. Lienau (2014, p.19) is right: debt continuity is not an “inevitable market principle". In fact, present "debt management” is the very opposite of the market mechanism. Speculators and risk loving investors are shielded from proper economic consequences of their decisions at taxpayers' cost. Former Communist economies were more market friendly: people really messing up were usually not promoted

In practice political might is often right. In the cases of Poland, Iraq and Cuba (around 1900, when the US invented odious debts) the US strongly and successfully advocated debt relief after and because of regime change. By strange coincidence neither the US government nor US banks were strongly exposed in these countries. In Latin America in the 1980s, where big US banks were most dangerously exposed - even at risk of being wiped out due to incautious and irrational lending, as well as incompetent regulation, called "regulatory risk" in literature - the US favoured the very opposite approach. No doubt another coincidence that sceptics are likely to misinterpret.

Lineau's basic argument is: historically one notices a movement from nonstatist to statist perceptions after WWII, and a new movement back to the prevailing view before WWII, which however is not yet strong enough to replace the statist view. Or, "different ideas of sovereignty have existed in political and legal thought and practice for a long time” (Lienau 2014, p.10). Her remark that "[M]ainstream approaches ... implicitly assume that it is theoretically untenable and impracticable to suggest alternatives to the current expectation of consistent repayment, or to ask about ideas of sovereign legitimacy underlying debt and reputation" Lienau (2014, p.55) puts things in a nutshell. Lienau shows that there are "alternative, plausible approaches to debt obligations."(Lienau 2014, p.55)

Early on she clarifies one shocking difference between municipal laws and international malpractice: "any so-called contract made by a deranged junior employee who has taken the company hostage is unlikely to be respected ... because there is no legitimate agency relation" (Lienau 2014, p.23) The exception to this fundamental cornerstone of any legal system is developing countries. Creditors' obligation to check whether someone signing has the authority to sign for a legal personality is the very cornerstone of law, just as any notary would have to check whether Ms Smith is actually Ms Smith. One may phrase differently: it is not "the lack of a clear theory of agency" (Lienau 2014, p.23) - there are no similar problems with OECD countries - but simply different treatment and standards applied to rich and poorer countries, a global, legal system minds more critical than I might call legal apartheid: anything goes with debtor 
countries, except when debtors are powerful OECD (Organisation of Economic Co-operation and Development) members. Cases such as enforcing debts if contracts were signed without proper authority - very frequent in the South are not a question of statist or non-statist theory but of brute power unrestrained by legal principles.

After an introductory part, the book describes Soviet repudiation in great and highly interesting detail, as well as the famous Costa Rican Tinoco case, the pet case of all advocates of odious debts. The author elaborates details worth knowing. Thus, she shows that US banks would have been more than willing to lend to the Soviets, whose repayment reputation for Soviet (not tsarist) debts was impeccable (Lienau 2014, pp.88ff), but were reined in by the US government for political reasons (Lienau 2014, p.89).

Interesting details emerge in the well known Costa Rican case. Suffice it to say that Britain sent a warship to Costa Rica (Lienau 2014, p.108), probably the last case of military intervention in debt issues. One has to point out, though, that - unlike in Copenhagen, when Denmark declared her neutrality in the Napoleonic wars or the Germans in Venezuela in 1902 - no shots were fired into Costa Rica, in a way a visible advance in civilized Northern behaviour.

Her next chapters discuss the situation after WWII, legitimacy, and debt at the turn of the century. Chapter 8 (Politics and Prospects) may be seen as a conclusion.

Agreeing with most points Lienau makes, this contribution aims at complementing rather than contradicting her line of argument, although one or the other comment might be also interpreted as a contradiction. A bit similar to sometimes quite large - footnotes it wants to corroborate her points or to bring up aspects that the book does not discuss. The two main comments are on the more civilized treatment of sovereign debtors before World War II, and on the role of the Bretton Woods Institutions after 1945 that - as Lienau correctly notes - changed the positon of debtors fundamentally. Finally, the new movement back to a non-statist regime she observes is commented on.

\section{Paradise lost: when lending was still more in line with the rule of law and market efficiency}

Linau starts with the early twentieth century, which is a pity as the nineteenth century and its debt crises would have sharpened her line of argumentation considerably. Debt crises happened in the US, Latin America and Europe, including the Ottoman Empire. After independence in 1829, Greece literally stumbled 
from one default to the next. Creditors tolerated massive and open buy-backs by debtor countries (for the following cf Raffer 2010, pp.1ff). Many countries could buy back up to half of their distressed bonds at secondary market prices. Economically this is identical to surreptitious default. Bolivia in 1886 or Ecuador in 1898 stand out as especially successful cases. Chile even had special entries in her budget to finance buy-backs. The US - then a developing country has an interesting history of non-payment. Quasi sovereign with regard to debts pursuant to the $11^{\text {th }}$ Amendment, US States have an impressive record of defaulting, which is even reflected in Dickens's Christmas Carol. One night Scrooge suffers a nightmare: his solid British assets have turned into a "mere United States' security." The US solved the question of State debts for good (legally and ethically rather for bad). The $11^{\text {th }}$ Amendment simply barred creditors from suing the debtor, rendering US States quasi sovereign (without any waiver of sovereignty) with respect to debts, depriving creditors of any legal relief. In a way, this Amendment is a No-Bailout Clause. It was introduced to avoid that the Union would have to pay for States' debts, proving the intention not to bail States out: if creditors cannot sue, enforced debt service cannot cause payment crises. Contrary to the case of Euro-countries that should have followed the US example - it has never been violated: no federal guarantee for State debts. This deserves mentioning as the US is now pressing other federal countries to guarantee the debts of their states or provinces. What's good for the US is obviously according to Washington - not good for other countries. Foreign bondholders circumventing the $11^{\text {th }}$ Amendment by suing at state courts, such as in Arkansas and Mississippi, did win their cases. The States, however, simply refused to obey their own courts and pay. The federal government itself defaulted on debts to France at the end of the eighteenth century. Ironically, the new republic argued that these were debts to the former king, but not to France. Although that matter was settled eventually - the US began to make regular payments on its French debts starting in 1790 - it shows that it is a wide-spread myth that the US - as opposed to its member States - has never defaulted. "In 1795, the United States was finally able to settle its debts with the French Government with the help of James Swan, an American banker who privately assumed French debts at a slightly higher interest rate. Swan then resold these debts at a profit on domestic U.S. markets. The United States no longer owed money to foreign governments" (US Department of State; U.S. Debt and Foreign Loans 1775-1795).

Mississippi seems to have coined the term repudiation when it simply refused to honour its debts. It was not the only case, though. Even referenda were held to vote whether (foreign) creditors should be paid. Some of the States defaulting during the 1840s paid - though not always all money due - when the situation improved, some never paid anything. The US railway system was largely financed 
by Europeans. Railway companies that enjoyed government support routinely went bankrupt, leaving foreign creditors with worthless papers and the US with the infrastructure. There once was a specific insolvency procedure for railways. There still exist specific legal norms for such companies today - Subchapter IV Railroad Reorganization, Chapter 11, Title 11 US Code. Established in 1868(!) the British Council of Foreign Bondholders has tried to get compensation for damages suffered because of unilateral breach of contract. In the 1940s nine US states suspended interest payments on loans they had received to build railways and canals, when the price of their main export good, cotton, left them short of resources. A look at the US' own past would have put US concern about "civilized international behaviour" in useful perspective, and would have strengthened her argument. Lienau (2014, p.96) describes this concern in her excellent Chapter on Soviet repudiation or the Roosevelt Corrolary (Lienau 2014, p.119) claiming the necessity of interventions to correct "chronic wrongdoing" by less civilized sovereigns not honouring their debts.

Reading that the International Bank for Reconstruction and Development (IBRD) expected the settlement of debts as old 1829 and of colonial rulers, insisting on a "reasonable settlement offer" (Lienau 2014, p.136), one cannot avoid mentioning that the IBRD has never even mentioned the US. This casts doubts on the Banks's honest intentions to establish a global rule, treating all countries equally.

The final outcome of Latin American's debt crisis in the 1930s may be seen as de facto insolvency. After negotiations Brazil's debts were reduced by over $75 \%$ in 1943. "Debt default eased payments constraints" (Maddison 1985, p.28) in Chile. Colombian local governments (municipalities, possibly) pioneered debt default, central authorities followed later. Some big European debtors were themselves delinquent regarding their debts after World War I. The British and French governments defaulted in the 1930s, considering their peoples' needs more important than legal obligations to creditors. The essence of this argument is familiar to insolvency specialists.

In 1876 the representatives of private bondholders, hard-nosed nineteenth century capitalists, decided to use Egyptian insolvency law as the yardstick to solve Egypt's debt crisis. Within a very short time they managed this crisis much better and more quickly than international public sector institutions nowadays, solving the problem.

After Mexico's default of 1914 the US Ambassador proposed following Egypt's example, but did not prevail. After years of debt management debt service was finally geared to Mexico's capacity to pay. Creditors received less than $10 \%$ of face values. The Egyptian solution would most probably have delivered a better outcome more quickly and more cheaply for anyone involved. 
Corroborating Lienau, though in slightly different wording, it can be shown that sovereign lending before 1945 was more in line with the Rule of Law, and economic reason. Occasional military interventions and threats notwithstanding, economic mechanisms and reason mostly prevailed before 1945. Risk was allowed to play its role. Legal principles, such as debtor protection and debtor rights, were generally accepted. After some negotiation and foot-dragging, claims were in most cases reduced by agreement. Suffice it to mention two examples Raffer (2013) uses to support this point:

1) Especially during the nineteenth century, international tribunals held that states were not bound by contracts made by someone without proper authority, so-called ultra vires contracts. When Venezuela's President Páez had his consul improperly enter into contracts that fell within the legislature's authority, claims under these contracts were rejected. In 1922, Costa Rica refused to honour a contract between the former dictator Federico Tinoco and a British oil company, a concession granted by him and approved by the Chamber of Deputies. The constitution would have required approval by both chambers. The new government repudiated the contract on the grounds that those who had entered it had acted ultra vires.

The very law rests on the condition that one can only be bound by contracts freely entered into and signed by oneself or- especially in the case of legal entities-by someone properly authorized to do so. Checking the authority to sign is an obligation of creditors. Lenders, who do not fulfil it, do so at their own peril, unless they lend to Southern Countries (SCs). Although this is self-evidently the very cornerstone of law, and such checks are routine for Northern corporate or sovereign debt, this principle has de facto been waived in sovereign lending with the support of Northern governments and International Financial Institutions (IFIs). To give but one example: Article 75 of the Argentine constitution reserves the authority to incur sovereign debts to Congress. Article 76 prohibits Congress from delegating this prerogative to the administration. Sovereign debts multiplied under the military dictatorship from $\$ 7.8$ billion in 1975 to $\$ 46$ billion in 1984 without one single loan raised in the proper, constitutional way. Her creditors, especially the official sector, made Argentina pay nevertheless. Lienau's "deranged junior employee" carried the day. No debtor, except an SC deprived of self-evident rights, would be expected to "honour" such null and void "contracts".

2) Although customarily cited as a case of odious debts, Taft's arbitral award in Costa Rica (described well in the book) simply applied due diligence and lenders' obligations. The Royal Bank of Canada "knew" or had to know that 
it was financing Tinoco's personal expenses. The problem boils down to equal treatment before the law. No creditor lending to a corporation's CEO, or to a cabinet minister in any OECD country, knowing that this money would be embezzled but lending nevertheless, could even dream of having this claim "honoured" by taxpayers. Quite to the contrary, lawsuits for damages by the legal entity and quite possibly penal law consequences would follow.

Lienau's (2014, p.213) quote "the odious debt argument was not acceptable inside the Treasury" in the case of Iraq needs some qualification. First, the US government revived its odious debt doctrine. Once enthusiastic reactions and calls to apply it in other cases as well made the US realize what it had done the administration started to back-pedal vigorously, finally denying it had ever advocated it. The damage of giving credibility to the doctrine was done, though. It could only be limited. (cf Raffer 2010, p.51ff)

One cannot but second Lienau: important changes occurred after 1945 mostly spearheaded by the official sector, which led to an international system some people are tempted to call the legal equivalent of apartheid. Looking a bit further down into history than she did, would have added considerable strength to her points.

\section{Institutional self-interest in violating one's own statutes}

Her point that the Bretton Woods Institutions (BWIs) promoted - one might also write installed - a strongly statist view is well taken, doubtlessly right and well documented. An economist is tempted to add an economic explanation. One can show that this serves their very own institutional self-interests to the point of openly and unashamedly violating their own statutes. Allowed to play a role by their statutes, the market mechanism was simply perverted into its opposite. The statist view has been necessary to support this illegal change, a welcome theoretical fig leave. One had to argue that everything must be repaid. Supporting the statist view is thus helpful. One should note that the quoted internal memorandum on risk taking (Lienau 2014, p.124) logically supports the non-statist view, encouraging the IBRD to observe traditional market practice before it was perverted in order to bail out under any circumstances. IFI practice has perverted this admonition.

Deliberately, their founders did not confer any preference on the BWIs. Quite the contrary, they stipulated subordination of BWI-claims. Before the Second Amendment, the IMF's Articles of Agreement “contained a provision 
suggesting that others would have preference on the Fund" (Martha, 1990, p.825). According to him the "intention" of this change by the Second Amendment "was not to repudiate the underlying thought that it was beneficial to encourage bank lending by giving banks and others a preference in repayment" (Martha, 1990, p. 814). Unfortunately, rather than making the IMF clearly financially accountable when conditionality was introduced, as economic reason would demand, initial intend was blurred, and it is now difficult to argue any longer that the IMF's claims are subordinated.

\subsection{Subordination rather than preference}

Clearly, no preferred creditor status was and is enshrined in its statutes. One may concur with Martha (1990, p, 814) that the IMF's statute contains "a presumption against a preferred creditor status", and that "general international law contains no compulsory standard of conduct requiring the preferential treatment of any external creditor, including the Fund.” (Martha, 1990, p.825) However, the IMF has no explicit statutory obligation to grant debt relief and got successfully rid of its explicit subordination to private creditors - part of its surreptitious and successful efforts to get rid of any economic accountability. Its attempt to legalise presently illegally enforced preference via the SDRM failed.

Trying to find arguments in favour of preference, the IMF could not deny that it enjoyed no legal or contractual status as a preferred creditor (Boughton, 2001, p.820). Its own Executive Directors emphasised a need (not a right!) to treat the IMF "in practice" preferentially - a legally irrelevant view to which anyone is, of course, entitled. The Interim Committee endorsed this view and "urged all members, within the limits of their laws, to treat the Fund as a preferred creditor" (Boughton, 2001, p.821, stress added). Unless all other creditors agree to grant preference to the IMF - which is clearly not the case when (rather than if) there are holdouts not agreeing to this IFI-"privilege" - the IMF continues violating the law. As long as only Southern or other minor members (such as Greece) are affected - no powerful OECD country has been insolvent recently - there is apparently no concern regarding the Rule of Law fervently preached to the countries suffering from this transformation of the Fund.

In the case of the IBRD the flouting of its own statutes is even more blatant. No article of the Bank's or IDA's statutes can be stretched to justify preference. By contrast, their Articles of Agreement still contain obligations that prove the founders' intention to subordinate these claims. Apparently, developmental tasks are the reason, quite as public interest in the global economic framework 
was in the case of the IMF. The IBRD's statutes not only recognise default as a fact of life. They contain obligations of the IBRD beyond those of a "normal" creditor. Technically, this means subordination.

Article IV, Section 4 of the IBRD's statutes speaks of a "relaxation of conditions of payment" in order to "modify the terms of amortization or extend the life of the loan". But the statutes go even further. At "its discretion" the Bank may also accept "service payments on the loan in the member's currency for periods not to exceed three years". In this case repurchasing of the member's currency "on appropriate terms" is stipulated. This may be extremely useful if a country has a short-term scarcity of foreign exchange, and is likely or foreseeably able to pay in foreign currencies later. Art. IV.4.c.i thus provides a valuable way to defuse short-term (illiquidity) problems that might otherwise trigger default, protracted debt problems, and losses suffered by other creditors. It just has not been used.

Article IV.4.c confers a right onto members suffering "from an acute exchange stringency" (viz. threatening default) to ask for relief. It stipulates:

If a member suffers from an acute exchange stringency, so that the service of any loan contracted by that member or guaranteed by it or by one of its agencies cannot be provided in the stipulated manner, the member concerned may apply to the Bank for a relaxation of the conditions of payment. ... (ii): The Bank may modify the terms of amortization or extend the life of the loan, or both.

Article IV.4.c specifically demands taking both the Bank's and such member's interests into account. Less repayment (debt reduction) is also a modification of the terms of amortization. One notices that no conditions are stipulated for such relief, except the member's urgent need for help.

The country has the right to ask for relief. The IBRD may - but need not grant it, but has to take the country's interest into account. The Bank does not have to grant relief whenever asked. Nevertheless, Art.IV.4.c certainly constitutes a general obligation to grant relief when and where appropriate, an obligation hardly reconcilable with the purported preferred creditor status, and the Bank's behaviour. Other creditors, most clearly the private sector, have no such obligation. They may eventually lose money, and they may grant relief by renegotiation, but they have no obligation to grant relief, let alone take the debtor's interest into account. Compared with the IBRD, IDA's Articles of Agreement are somewhat vaguer but mirror the statutes of its "mother". When IDA was established in 1960, its founders still wanted subordination. IDA's Article V.3 demands to take decisions on relief "in the light of all relevant circumstances, including the financial and economic situation and prospects of the member concerned". 
This indicates that the Bank's founders wanted to and did subordinate the IBRD's claims, maybe formulating so clearly because no sovereign insolvency procedure existed. Evidently, IBRD-claims are meant to rank behind other claims. Stretching Art.IV.4.c in favour of preference as much as logically possible, one could probably challenge the presumption of intended subordination, but even in this case and "forgetting" its statutory obligations, one could not do more than claim that the statutes put the IBRD on an equal footing with other creditors. Even this biased interpretation would result in the very opposite of preference. The often heard "argument" that relief for multilateral debts cannot be granted or would make development finance inoperable, was not shared by the IBRD's and IDA's founders formulating their respective Articles of Agreement. The EBRD proves that properly managed development banks can survive without that privilege by accepting both arbitration and losses. Steadfastly denying debt relief, claiming to be a preferred creditor, forcing member countries not to avail themselves of their statutory rights is definitely at severest odds with statutory duties, good governance, and the Rule of Law.

Logically, the IBRD's Articles of Agreement request it to prepare for default. Article IV.6 demands a special reserve to cover what Article IV.7 calls "Methods of Meeting Liabilities of the Bank in Case of Defaults." Art.IV.7 clearly formulates: "In cases of default on loans made, participated in, or guaranteed by the Bank: (a) The Bank shall make such arrangements as may be feasible to adjust the obligations under the loans, including arrangements under or analogous to those provided in Section 4 (c) of this Article." As the Section 4.c explicitly allows debt relief, it would be difficult to argue that the obligations to be adjusted exclude the debtor's obligations to the IBRD. Other creditors, especially the private sector, may proceed in the same way, but unlike the Bank they are not obliged to do so. The statutes of international development banks founded later mirror the statutes of the IBRD, although language is usually not that clear (cf Raffer 2009).

Checks of the IBRD, inter alia by Canada's auditor-general, concluded that it has no preferred status. Under pressure from private business the IBRD even waived the negative pledge clause in its loans in 1993 (Caufield 1998, p.323). If it had been de jure preferred there would have been neither need nor scope for such clause, nor for pressure to waive it, as legal norms always prevail. It is one rare occasion where private creditors asserted their rights vis-à-vis IFIs. By waiving this right, the IBRD acknowledged that its claims should not be treated in the same way as private claims, but should be subordinated to them, in line with their founders' intentions.

The IBRD's founders understandably wanted lending to be subject to some market discipline - as also proved by clauses allowing the IBRD to be sued or 
allowing members legal redress via arbitration - designing mechanisms that would allow the Bank to shoulder its fair share of the risks involved, another clear sign that no preferential treatment was and is wished as these clauses are part of the presently valid statutes. All MDBs have the statutory duty to reduce their claims in the case of default.

While IBRD and IDA are already held by their statutes to avoid default by relaxing their terms, their Articles of Agreement are absolutely clear as regards default itself. Logically, the IBRD is meant to grant relief well before others. Its own statutes subordinate its claims. In accordance with its statutes, the IBRD has charged its members spreads in order to finance these reserves, but, in breach of its statutory obligations, it has refused to use them, claiming this would make development finance impossible.

Not acting as stipulated, the Bank, IDA, and other MDBs have inflicted gravest damage on members under duress, SCs forced to turn to them for help because of acute foreign exchange stringency. Other creditors, especially the private sector, have no similar obligations. Logically, this supports the view that these multilateral institutions are meant to grant relief well before others in order to avoid liquidity problems, and their statutes legally subordinate their claims. Using the possibilities allowed, even suggested by their statutes and obviously intended by their founders would doubtlessly have defused quite a few crises, and saved the poor much misery, and other creditors a lot of money.

The way the IBRD tries to skirt the obligation to declare default, which would trigger its statutory duty to reduce claims no longer borders the ridiculous. It simply refuses to acknowledge default, even when countries have not paid anything for six or seven years (Caufield 1998, p.319) Claiming no default as long as debtor countries stay "in mutual respectful contact" (Caufield 1998, p.319), the IBRD mocks all acceptable accounting rules on doubtful debts. Real banks emulating this would definitely not be considered as models of best practice and good governance and might even see their managers in jail.

The demand that the Bank remain "politically 'neutral”" (Lienau 2014, p.125) requests in no way a statist approach. Statist continuity is as apolitical and economic as debt reduction. One should add that this provision has been continuously violated by the IBRD siding with fascist military dictators and against democratic regimes (as Allende's in Chile where lending started immediately after the military junta took over, Brazil after Goulart's democratic regime had been overthrown, Somoza, Suharto, the Argentine military junta, Mobutu, Ceaucescu -arguably a Stalinist rather than a fascist, but hardly better - Marcos, to name but a few; cf Strahm 1985, pp.176f; Toussaint 2014), or by intervening into political decisions, claiming that good governance or the Rule of Law (not observed by IFIs themselves) were non-political issues. 
Regarding private claims, IFIs have acted incorrectly too. Claims that were known to have no legal basis were treated as perfectly legal and legitimate debts. According to the IBRD "governments in many of these countries were forced to assume the losses suffered as a result of the external debts of private banks and corporations, which further worsened the burden on the budget. “(IBRD 1988, p. xx) Neither the BWIs nor creditor governments did criticize this practice. Although such ex post "nationalisation" under pressure made debt management more difficult and is clearly illegal, the BWIs and Northern governments insisted on punctual service of these void debts as well - all the while busily preaching the Rule of Law to debtors whose basic right only to honour contracts freely and voluntarily entered into, they were aiding and abetting to crush. Chile in the early 1980s is one prominent example of such "nationalised" debts, which had initially been incurred without any government involvement and while the government declared that it would neither intervene in private contracts nor bail out private debts. Banks tried to cover themselves after the crisis broke. This open breach of the law would not have been possible if official creditors had not tolerated or abetted it. Obviously the motto has been "anything goes", when it comes to the South and poor people: legal formalities such as authorisation to sign or creditor's duties not to aid and abet embezzlement relevant normally, are irrelevant The BWIs have turned their founders' intention to "drive ... usurious money lenders from the temple of international finance” (Lienau 2014, p.129) into its very opposite, protecting even void claims.

\subsection{Lack of liability and misallocation of resources}

But IFIs, most notably the BWIs, also helped bring about substantial misallocation of resources, both directly within borrowing countries and indirectly by preventing otherwise viable investments elsewhere. Commercial banks did not act irrationally, though. Convincing evidence exists that they had reason to assume that their claims would be protected against the market by governments that are OECD-members. Not bothering about economic fundamentals was thus explicable and-from a business-administration point of view-rational. An enormous moral hazard problem was created by the public sector. Lienau (2014, p.233) puts her finger on this problem, speaking of lending to questionable ends. One should point out that this is not really the "effect of a purely statist approach". Legally, one would understand that debt continuity can only be demanded if the usual essential elements are met, such as contracts signed by persons authorized, parliamentary approval (where and if legally required), no aiding and abetting embezzlement by politicians. If debtors are forced to pay 
just anything a lender claims, including on occasion calculation errors in favour of creditors (cf e. g. Bindert 1985, p.145; verifying loan-by-loan Costa Rica saved almost $10 \%$ of interest in arrears), one should not speak of debt continuity but of openly violating the very essence of any decent legal system.

Very briefly after Indonesia had received substantial debt relief (including from private lenders, although their share was quite small), Indonesia's national oil company, Pertamina, could already amass enough debt to go belly up. Lienau (2014, p.164) mentions this case, noting that "both the US Embassy and the IMF were concerned about excessive lending”. But there is more to it.

According to a Report by the US Senate Committee on Foreign Relations (1977) no one, including commercial banks themselves, seemed to know how much precisely was owed. A one year stand-by agreement was concluded with the IMF, putting a ceiling on Indonesia's external borrowing and a specific sub-ceiling on Pertamina's. Foreign banks rushed in to go on lending, using technical tricks (such as rolling over short term loans) to escape those ceilings. Warnings and "direct representation" (US Senate Committee on Foreign Relations 1977, p.22) by the US embassy went unheeded. Convinced that they would be bailed out banks went on lending. When the crisis broke the US government immediately helped. The Committee concluded that "the Indonesian situation" could be repeated any time (as happened later on) and Senator Sarbanes expressed his fears that the Senate would soon be forced to vote for payments to debtor governments to bail out US banks. The Committee concluded: "Conceptually, the independence of private bank lending activities overseas would be fine if the banks were actually made to bear the ultimate risk." Intervention of creditor governments "calls into question the justification - the high degree of risk involved... for the high rate of interest banks charge to developing countries. Thus it is the creditor governments, not the banks, which are really bearing the risk." (US Senate Committee on Foreign Relations 1977, p.22).

Lienau (2014, pp.164f) also mentions the case of Iran under the Shah where money was lent against the constitution and against the warning of legal advisors. The banks insisted on full repayment.

Winters (2004) coined the term "criminal debts". These are debts originating from loans IFIs disbursed to corrupt governments, such as Suharto's in Indonesia, knowing that large parts of these loans would be embezzled. The parallels with the Tinoco case are obvious. Unlike in the Tinoco case, Indonesia had to "honour" these debts too. Such criminal debts amounted to 25 to 33 per cent of all loans. IBRD employees admitted only $25 \%$ publicly, but on practically all loans. That much had routinely been embezzled with full knowledge and toleration of the lender, the IBRD. Compared with Taft's award, this is a visible 
drop in legal standards, an abolition of law itself. Before the era of the BWIs such lending would in all likelihood not have obliged a debtor to full repayment.

Demands for full repayment of IFI-loans that knowingly damaged the borrower has been "supported" by the claim to enjoy preferred creditor status. Existing mechanisms allow taking IFIs to court or submitting to arbitration (the IMF would have to waive immunity), but no debtor dares use them. Thus, IFIs gain from their own failures and negligence. They insist on full repayment, even if damages negligently caused by their staff occur, which have to be paid by borrowers. A high rate of IFI-failures thus renders further adjustment programmes necessary, which are administered by IFIs, just as failed programmes are likely to call for new programmes, as long as unconditional repayment to IFIs is upheld. IFIs earn more if programmes and projects fail. They need more humanpower, gaining from their own failures and negligence. This logical mechanism might be described somewhat cynically as "IFI-flops securing IFI-jobs.” (Raffer 1993, p.158). It fosters lending without any regard for the real needs of debtors, indeed, it rewards knowingly inflicting damage on the poor.

Brazil's Polonoroeste illustrates the glaring difference perfectly. Time (12 December 1988) reported that a loan of $\$ 240$ million granted despite warnings from the Bank's own experts (cf. also Rich 1994, pp.141ff), had caused considerable environmental damage. Bank officials admitted that they had erred and lent another \$200 million to repair the damage done by the first loan. Brazil's debts increased by $\$ 440$ million, the IBRD increased its income stream (cf Raffer 1993, p.156f or Raffer 2010, p.230).

Probably such eventuality made the IMF's founders insert the waiver in Art. IX.3, providing for proper legal dispute settlement. When conditionality became enshrined in the IMF's statutes in 1969, the appropriate change regarding immunity was not made for whichever reason, although its founders would doubtlessly have stipulated the possibility of legal redress as clearly as they did with the IBRD if they had approved conditional drawing. Arguably, this was the first step to establish legal double standards globally, isolating the IMF from lawsuits even though it could now and actually has forced economic policies on countries. This amounts to taking decisions without having any financial responsibility, and led to gravest negeligence even dolose behaviour (for concrete examples cf Raffer 2010, pp.231f). Nevertheless, the IMF may not only submit to arbitration or courts, but contractual clauses stipulating this remain expressly allowed. Nothing in its statutes prevents the IMF from applying civilized legal standards. On the contrary, the existence of this waiver seems an encouragement to do so if and when appropriate.

By not availing itself of this option when and where appropriate, the IMF has knowingly created a system incompatible with the very idea of the market 
economy, good governance, or the Rule of Law. The only exception of the generally accepted principle that someone inflicting damage unlawfully, especially dolosely, must compensate their victims is unfortunately development cooperation, the last sphere where damage can still be inflicted with impunity and even financial and "reputational" gain. If normal accountability standards applied to Southern debtors there would in all likelihood be no multilateral debt problem.

\section{Recent tendencies back to non-statism?}

Considering that all historical cases of sovereign debt overhang prove that debts must eventually be reduced by substantial amounts reduces the practical relevance of the dichotomy statist - non-statist considerably. During 1970-2002 19 out of 26 cases of large debt reduction "were associated with a debt default.” (IMF 2003, p.140)

Although the early period after WWII has been characterized by debt continuity, there were two spectacular cases of de facto insolvency after 1945: Germany's London Accord and Indonesia’s reduction 1969. Both roughly halved the present values of debts, both were politically motivated. Recalling them might be useful to prove that debt continuity was not always accepted or enforced by its most vocal defenders. But they were definitely not the rule.

Comparing Germany's debt indicators with those considered "generous" under HIPC II shows a technically inexplicable difference between debtors. Germany's Debt Service Ratio (debt service divided by export earnings) before debt reduction was below $4 \%$. Unlike $15 \%$ for HIPC II this was considered unsustainable. Its debt (stock)/exports ratio was well below $100 \%$. No doubt Germany's reparations after World War I, which the country had to pay against Keynes's advice, were one important reason why Germany's debt burden relatively much lower than the burden of many SCs - was seen as unbearable for a sovereign debtor in the 1950s, stifling Germany's economy. Greece and Ireland, creditors forgiving German debts in 1953, became recently victims to Germany's adamant attitude that debtors - unlike Germany itself - have to repay all debts on moral grounds. The "loan" Germany extorted from the Greek central bank in the 1940s has never been repaid too, nor have payments been made Germany had agreed to under the London Accord. Clearly, Germany is no longer as weak as in 1953. In a first period after 1953 Germany invoked the "legal benefit" of the London Accord not to have to pay before a conference on reparations, which Germany has thwarted successfully later with a great deal of effort. Meanwhile Germany refuses to pay, claiming that its stipulated obligations were already antiquated, chiding the Greek why they did not demand payment earlier, although they had actually done so. 
Although an SC, Indonesia was strategically most important after the putsch against Sukarno. After the new Suharto regime had allied itself with the West, proving its staunch support for freedom and democracy by slaughtering many thousand real or alleged communists, the new Western ally had earned a proper compensation. The US - incidentally not having many claims if any at all strongly pressed for debt reduction. It turned out to be German type debt relief including equal reductions of claims by the East. Germany already opposed debt reductions on moral grounds but had a difficult stance, especially so as the master mind behind Indonesia's solution was the same German banker, who had engineered Germany's own debt reduction. Unlike in Greece or Ireland today, they could not really speak out loudly.

In the early 1990s Poland benefitted from a generous debt reduction. The US, once again having very few if any claims was the engine. In 1991 Senate Resolution No. 84 praised the people and the Government of Poland for their efforts in trying to transform their economy, specifically referring to the "precedent" of the "London accord after World War II". (Raffer 2010, p.21). Once again all those official creditors otherwise most staunchly defending debt continuity were happily granting generous debt reduction.

More and more countries have recently resorted to unilateral actions. Argentina is arguably the best known example. Such actions are emergency solutions, necessary because proper sovereign insolvency proceedings are unavailable, a second best solution or optimization under restrictions. Fair and Ruleof-Law-based insolvency proceedings would definitely have been better. Ecuador (described in Lienau 2014, pp.215ff) put pressure on creditors via her debt audit commission, receiving a large reduction after quite an unpleasant debate.

Apparently, Ecuador's Integral Auditing Commission was meant to frighten creditors rather than produce proper legal arguments. In this respect it was successful. Enumerating several examples, Richards (2010) identified a clear trend toward unilateral exchange offers as a technique for restructuring sovereign debt. When Congo (Brazzaville) - after a series of restructurings in which creditors were either completely bypassed or slighted after initial overtures for dialogue - responded favourably to promoting a negotiated solution over unilateral exchange offers, he called this "a ray of sunshine cutting through the shadow cast by the cases of Ecuador and Argentina.” (Richards 2010, p.298) Without a fair solution, debtor countries had to become more assertive. Iceland refused to nationalise the debt of her private banks, resisted considerable pressures, by the UK and the Netherlands in particular, exited from the crisis quickly and is meanwhile called a success by the IMF (2011). Ukraine's behaviour vis-à-vis creditors - although supported by the West for political reasons also shows a new attitude. 
Thus, one may well see signs of another change in perceptions of sovereign debt. The UN initiative for sovereign insolvency procedures clearly shows a huge and justified desire for change, although it should not be seen in the statist or non-statist perspective. Debtors other than sovereigns may go bankrupt without a "change in management" and any thoughts about whether there should be continuity in their debts. This UN initiative is thus only another attempt finally to establish the Rule of Law also for the South.

But there also is at least one distinct movement the other way: the reaction during and to the crisis in Euroland. Public creditor behaviour cannot simply be described by statist. That would be incorrect and grossly unfair. As the private sector suffered haircuts (see e. g. Roubini 2012), Greece did not pay her initial debts anyway. Claiming untruthfully that Greece would repay her private creditors and that they would help to do so, an incompetent official sector has inflicted severe damages on the country and its people, turning a small problem into catastrophe (cf Raffer 2014). Suffice one fact: when the crisis broke, Greece had a relation debts/GDP of roughly 120 per cent, mid-2015 it is roughly 180, and the IMF already estimates it to reach or surpass 200 - in spite of massive debt reductions from private creditors. Greece would have been much better off without any EU-Type "rescue", but a proper sovereign insolvency procedure (this author's favourite model is Raffer 1990; also described in Raffer 2010, pp.78ff). But debts are apparently not the real point. If it were, the result of "rescue operations" bringing the relation debts/GDP from about 120 to about 180 (the IMF even fearing 200) would demand changes in debt management. As no changes have been made, but more of the same is demanded, another explanation must hold. Economically colonializing Greece and forcing privatization at fire sale prices seem the real issues. Asset grabbing is a much more plausible explanation for what happens in Greece. If Germany, e. g., actually believed in what it claims and debt continuity, it would have paid off its Nazi debts. It might also be explained by the desire to make Greece a terrifying example warning other member countries likely to become bankrupt.

\section{Conclusion}

Commenting on Lienau's stimulating book two main comments were made: the more civilized treatment of sovereign debtors before World War II and the role of the Bretton Woods Institutions after 1945 that - as Lienau correctly notes changed the position of debtors fundamentally. Especially so, after they took over as "debt managers" after 1982. To some extent this can be explained by 
institutional self-interest. Finally, the new movement back to a non-statist regime the author observes is briefly commented on.

\section{References}

Bindert, C. (1985). Debt and development crisis: The case of small- and medium-size debtors. In K. Haq (Ed.), The Lingering Debt Crisis (pp. 141-52). Islamabad: North-South Roundtable. Boughton, J. M. (2001). Silent Revolution: The International Monetary Fund 1979-1989. Washington, DC: IMF. Chapter 16 http://www.imf.org/external/pubs/ft/history/2001/ch16.pdf.

Caufield, C. (1998). Masters of Illusion, The World Bank and the Poverty of Nations. London: Pan. Espósito, C., Y. Li \& J. Pablo Bohoslavsky (Eds.) (2013). Sovereign Financing and International Law, The UNCTAD Principles on Responsible Sovereign Lending and Borrowing. Oxford etc.: OUP.

IBRD (1988). World Debt Tables. vol.1.

IMF (2003). World Economic Outlook. September.

IMF (2011). Iceland's unorthodox policies suggest alternative way out of crisis. IMF Survey online, 3 November, www.imf.org/external/pubs/ft/survey/so/2011/car110311a.htm

Lienau, O. (2014). Rethinking Sovereign Debt, Politics, Reputation, and Legitimacy. Cambridge, MA \& London: Harvard UP.

Maddison, A. (1985). Two Crises: Latin America and Asia 1929-38 and 1973-83. Paris: OECD.

Martha, R. S. J. (1990). Preferred creditor status under international law: The case of the international monetary fund. International and Comparative Law Quarterly, 39(4), 801ff.

Raffer, K. (1990). Applying Chapter 9 insolvency to international debts: An economically efficient solution with a human face. World Development, 18(2), 301ff.

Raffer, K. (1993). International financial institutions and accountability: The need for drastic change. In S. M. Murshed \& K. Raffer (Eds.) Trade, Transfers and Development, Problems and Prospects for the Twenty-First Century (pp. 151ff). Aldershot: Edward Elgar. or at http://homepage.univie.ac.at/kunibert.raffer/ifiacc.pdf.

Raffer, K. (2009). Preferred or not preferred: Thoughts on priority structures of creditors. Paper presented at the $2^{\text {nd }}$ Meeting of the ILA Sovereign Insolvency Study Group, 16 October 2009, Washington, DC.

Raffer, K. (2010). Debt Management for Development - Protection of the Poor and the Millennium Development Goals. Cheltenham \& Northampton, MA: Edward Elgar. Paperback: 2011

Raffer, K. (2013). Improving debt management on the basis of UNCTAD's principles. In C. Espósito, Y. Li, and J. Pablo Bohoslavsky (Eds.). Sovereign Financing and International Law, The UNCTAD Principles on Responsible Sovereign Lending and Borrowing. pp.163ff. Oxford etc.: OUP.

Raffer, K. (2014). Turning a small problem into catastrophe: The case of Greece. In D. Dăianu, G. Basevi, C. D’Adda \& R. Kumar (Eds.), The Eurozone Crisis and the Future of Europe - The Political Economy of Further Integration and Governance (pp. 154-170). Basingstoke \& New York: Palgrave Macmillan.

Rich, B. (1994). Mortgaging the Earth, The World Bank, Environmental Impoverishment and the Crisis of Development. London/Boston: Earthscan/Beacon. 
Richards, M. B. (2010). The republic of Congo's debt restructuring: Are sovereign creditors getting their voice back? Law and Contemporary Problems, 73(4), 273-299.

Roubini, N. (2012). Greece's private creditors are the lucky ones. FT 7 March, http://www.ft.com/ intl/cms/s/0/f0f0708e-679d-11e1-b6a1-00144feabdc0.html\#axzz45dZtqgu0.

Strahm, R. H. (1985). Warum sie so arm sind. Wuppertal: Hammer.

Toussaint, E. (2014). World Bank and IMF support to dictatorships. Committee for the Abolition of Third World Debt, http://cadtm.org/World-Bank-support-to.

US Senate Committee on Foreign Relations (1977). Bretton Woods Agreements Amendments Act of 1977, United States Senate, 95th Congress, 1st Session, Report No. 95-603 (Washington DC: Government Printing Office

US Department of States, Office of the Historian (no date). Milestones: 1784-1800.

U.S. Debt and Foreign Loans, 1775-1795. https://history.state.gov/milestones/1784-1800/loans.

Winters, J. (2004). Criminal Debt, written statement for Combating Corruption in the Multilateral Development Banks. Hearing before the Committee on Foreign Relations, U.S. Senate, 108th Congress, 2nd session, May 13, http://foreign.senate.gov/imo/media/doc/ WintersTestimony040513.pdf. 